\title{
3. Factor L (Vitamin L) Requirements for Lactation in Parous Rats.
}

\author{
By Waro NaKaHaRa, Fumito InUKaI \\ and Saburo UGAMI. \\ Institute of Physical and Chemical Research, Tokyo. \\ (Comm. by U. SuzukI, M.I.A., Jan. 12, 1938.)
}

We have previously demonstrated that there exist two hitherto unknown dietary factors, factors $\mathrm{L}_{1}$ and $\mathrm{L}_{2}$, both specifically essential to the process of lactation. They may be regarded as vitamins (vitamins $L_{1}$ and $L_{2}$ ) in that the animals depend entirely on dietary supply for both, which are effective in minute amounts, and the absence of which from the otherwise complete diet produces a total failure of lactation. These conclusions are based on a long series of lactation experiments on rats, carried out by us during the past several years. ${ }^{1) 2 \text { (3) 4) }}$

All these experiments, however, were confined to the lactation in the case of the first birth, as we used virgin females exclusively in order to standardize the experimental conditions. It must be pointed out that physiological conditions, and consequently dietary requirements of subsequent lactations may not be exactly the same as those of the first lactation.

During the past year we have been able to obtain two series of experimental data concerning the effect of factor $L$ deficient diet on lactation in parous rats, i. e., the second lactation, and these data are now presented in this paper with the hope that they may serve to further define the vitamin-nature of factor $L$ in lactation.

The first series of our new data consists of the lactation records of 9 female rats which were carried through first and second births exclusively on a factor $\mathrm{L}$ complex deficient diet. The composition of this diet was: Polished rice powder, $75 \mathrm{~g}$; fish protein, $10 \mathrm{~g}$; butter, $10 \mathrm{~g}$; McCollum's salt mixture, $5 \mathrm{~g}$; supplemented with acid earth adsorbate of extract of baker's yeast (vitamin B complex) in amount corresponding to the yield from $10 \mathrm{~g}$ of dried yeast. In this experiment the period of deficient feeding before the first parturition varied from 17 to 34 days, and the total period before the second parturition, from 42 to 73 days. A total failure of lactation occurred in every case without exception, as may be seen in Table 1 .

1) W. Nakahara and F. Inukai: Sci. Pap. Inst. Phys. Chem. Res, 22 (1933) 301; 24 (1934) 33.

2) W. Nakahara, F. Inukai and S. Kato: Proc. 10 (1934) 268; Sci. Pap. Inst. Phys. Chem. Res., 24 (1934) 155.

3) W. Nakahara, F. Inukai, S. Kato and S. Ugami: Sci. Pap. Inst. Phys. Chem. Res., 29 (1936) 47.

4) W. Nakahara, F. Inukai and S. Ugami: Proc. 11 (1935) $362 ; 12$ (1936) 289 ; Sci. Pap. Inst. Phys. Chem. Res., 28 (1935) $152 ; 31$ (1937) 42. 
TABLE 1.-First and second lactations on factor $\mathrm{L}$ complex deficient diet.

\begin{tabular}{c|c|c|c|c}
\hline $\begin{array}{c}\text { Female } \\
\text { No. }\end{array}$ & \multicolumn{2}{|c|}{ First birth } & \multicolumn{2}{c}{ Second birth } \\
\hline & $\begin{array}{c}\text { No. of young } \\
\text { born }\end{array}$ & $\begin{array}{c}\text { No. of young } \\
\text { reared }\end{array}$ & $\begin{array}{c}\text { No. of young } \\
\text { born }\end{array}$ & $\begin{array}{c}\text { No. of young } \\
\text { reared }\end{array}$ \\
\hline 1 & 3 & 0 & 7 & 0 \\
2 & 3 & 0 & 4 & 0 \\
3 & 8 & 0 & 7 & 0 \\
4 & 7 & 0 & 5 & 0 \\
5 & 6 & 0 & 7 & 0 \\
6 & 3 & 0 & 7 & 0 \\
7 & 6 & 0 & 9 & 0 \\
8 & 8 & 0 & 3 & 0 \\
9 & 2 & 0 & 55 & 0 \\
\hline Total & 46 & 0 & 5 & 0 \\
\hline
\end{tabular}

The second series of data is represented by lactation records of 10 female rats which were first maintained on an adequate diet (containing factor $\mathrm{L}$ ) with normal lactation at the first birth, and then transferred to a factor $\mathrm{L}$ deficient diet to test its effect on lactation at the second birth. The adequate diet used was either natural food (whole wheat, dried fish and some vegetables) or a synthetic diet with factor L supplement.

The period of factor $\mathrm{L}$ deficient feeding before the second parturition varied from 32 to 91 days. We used two kinds of deficient diet; one deficient in factor $\mathrm{L}$ complex $\left(\mathrm{L}_{1}\right.$ and $\left.\mathrm{L}_{2}\right)$ described above, and the other deficient in factor $L_{1}$ only. The composition of this second diet was the same as that of the first, but supplemented with $5 \mathrm{~g}$ of dried whole baker's yeast (vitamin $B$ complex plus factor $L_{2}$ ), instead of with acid earth adsorbate of the yeast extract (vitamin B complex without factor $\mathrm{L}_{2}$ ). As may be expected from the known reciprocal relation between factors $L_{1}$ and $L_{2}$, these two kinds of diet gave practically identical results, which may be tabulated together as follows:-

TABLE 2.-Effect of factor $L$ deficient diet on second lactation after first normal lactation on adequate diet.

\begin{tabular}{c|c|c|c|c}
\hline \multirow{2}{*}{$\begin{array}{c}\text { Female } \\
\text { No. }\end{array}$} & \multicolumn{2}{|c|}{ First birth (With factor L) } & \multicolumn{2}{c}{ Second birth (Factor L deficient) } \\
\cline { 2 - 5 } & $\begin{array}{c}\text { No. of young } \\
\text { born }\end{array}$ & $\begin{array}{c}\text { No. of young } \\
\text { reared }\end{array}$ & $\begin{array}{c}\text { No. of young } \\
\text { born }\end{array}$ & $\begin{array}{c}\text { No. of young } \\
\text { reared }\end{array}$ \\
\hline 1 & 8 & 7 & 10 & 9 \\
2 & 8 & 8 & 8 & 5 \\
3 & 11 & 8 & 10 & 0 \\
4 & 10 & 9 & 8 & 9 \\
5 & 8 & 6 & 9 & 0 \\
6 & 10 & 9 & 9 & 8 \\
7 & 10 & 9 & 9 & 0 \\
8 & 9 & 4 & 10 & 10 \\
9 & 5 & 8 & 90 & $52(50.7 \%)$ \\
10 & 8 & $77(88.5 \%)$ & & 10 \\
\hline Total & 87 & & & $7(70.0 \%)$ \\
\hline
\end{tabular}


The first series of results described above may be sufficient to show that factor $L$ deficient feeding brings about a total failure of lactation not only in the case of the first birth but also at the second birth as well, as long as the rats are continued on the same deficient diet.

The second series of results, dealing with the rats with the record of normal first lactation on adequate diet, is not so conclusive. The fact that the second lactation on factor $\mathrm{L}$ deficient diet proved a failure in some cases may be taken as a manifestation of factor $L$ deficiency, and so may lead us to suppose that a total failure of the second lactation may be produced by using more strictly factor $\mathrm{L}$ free diet or even by greatly prolonging the period of feeding on our present diet. In any event, these results show that if the lactation mechanism is established at the first birth in the presence of factor L, this latter may no longer be needed for the second lactation in so large an amount as is absolutely necessary for the first lactation.

It may, therefore, be concluded that factor $\mathrm{L}$ is a vitamin (vitamin L) which is necessary for the establishment of normal lactation, but once this mechanism is established the factor $L$ requirement for the second lactation may become decidedly smaller. This is in keeping with the case of other vitamins, all of which are required much less by mature animals than by immature ones.

The details of this work will appear shortly in "Scientific Papers of the Institute of Physical and Chemical Research." 